\title{
KONSUMSI PROTEIN, LEMAK JENUH DAN LEMAK TAK JENUH TERHADAP KEJADIAN HIPERTENSI PADA WANITA MENOPAUSE DI WILAYAH KERJA PUSKESMAS SUKAMERINDU KOTA BENGKULU
}

\author{
THE CONSUMPTION OF PROTEIN, SATURATED FAT AND SATURATED \\ FATTING ON THE HYPERTENSION IN MENOPAUSE WOMEN \\ AT PUBLIC HEALTH CENTER SUKAMERINDU IN BENGKULU
}

\author{
Aulia Fianti Ramadhini ${ }^{1}$, Emy Yuliantini, Miratul Haya \\ Politeknik Kesehatan Kementerian Kesehatan Bengkulu, Jurusan Gizi \\ (penulis penulis korespondensi: auliafianti@gmail.com)
}

\begin{abstract}
ABSTRAK
Latar belakang: Hipertensi adalah suatu keadaan terjadinya peningkatan tekanan darah diastolik maupun sistolik. Penelitian ini bertujuan untuk menganalis hubungan konsumsi protein, lemak jenuh dan lemak tak jenuh dengan kejadian hipertensi pada wanita menopause di Wilayah Kerja Puskesmas Sukamerindu Kota Bengkulu.

Metode: Penelitian ini merupakan observasional analitik dengan desain cross sectional dengan jumlah sampel sebanyak 67 responden yang diambil dengan teknik purposive sampling. Pengumpulan asupan protein, lemak jenuh dan lemak tak jenuh dilakukan dengan metode wawancara menggunakan Food Frequency Questionaire (FFQ) semi kuantitatif. Analisis bivariat menggunakan uji chi square. Hasil: Penelitian menunjukkan bahwa wanita menopause yang mengalami hipertensi sebanyak 52,2\% dengan konsumsi protein tidak baik 62,7 \%, konsumsi lemak jenuh (SFA) tidak baik sebanyak 80,6\% sedangkan pada konsumsi lemak tak jenuh tunggal (MUFA) sebanyak 94\% dan konsumsi lemak tak jenuh tak jenuh ganda (PUFA) sebanyak 50,7\%. Terdapat hubungan yang signifikan antara konsumsi protein dan lemak jenuh (SFA) dengan kejadian hipertensi sedangkan konsumsi lemak tak jenuh (MUFA,PUFA) tidak berhubungan dengan kejadian hipertensi.

Kesimpulan: Kejadian hipertensi pada wanita menopause dipengaruhi oleh konsumsi protein dan lemak jenuh (SFA), karena itu bagi wanita menopause diharapkan dapat meningkatkan asupan lemak tak jenuh (MUFA,PUFA).
\end{abstract}

Kata kunci: Konsumsi Protein, Lemak Jenuh, Lemak Tak Jenuh, Hipertensi, Menopause

\begin{abstract}
Background: Hypertension is increased blood pressure both diastolic and systolic that occur in a lost or sedentary. This research aims to determine the relationship of protein consumption, saturated fat and unsaturated fats with the incidence of hypertension in menopausal women in Sukamerindu work area Puskesmas in Bengkulu.

Methods: This research was an analytic observational with cross sectional design, the number of samples as many as 67 people taken with purposive sampling techniques. The collection of protein intake, saturated fat and unsaturated fats is done by the interview method using the Food Frequency Questionaire (FFQ), using bivariate analysis chi square test.

Results: The results showed that menopause women who with hypertension as much as $52.2 \%$ with no good protein consumption $62.7 \%$, consumption of saturated fats (SFA) is not good as much as $80.6 \%$ while in the consumption of monounsaturated fats (MUFA) as much as $94 \%$ and the consumption of polyunsaturated fats (PUFA) as much as 50.7\%. There was a significant between consumption of protein and saturated fats (SFA, but the consumption of unsaturated fats (MUFA, PUFA) was not related to hypertension.

Conclusion: The incidence of hypertension in menopause women was influenced by consumption of protein and saturated fat (SFA), therefore it was expected that menopause women must be increased their intake of unsaturated fats (MUFA, PUFA).
\end{abstract}

Keywords:Saturated fats (SFA), unsaturated fats (MUFA, PUFA), hypertension, Menopause 


\section{PENDAHULUAN}

Hipertensi adalah suatu keadaan terjadinya peningkatan tekanan darah baik itu diastolik maupun sistolik yang terjadi secara hilang timbul atau menetap. Hipertensi terjadi secara esensial (primer atau idiopatik) karena faktor penyebabnya tidak dapat diidentifikasi, atau secara sekunder, akibat dari penyakit tertentu yang dideritita. ${ }^{1}$

Wanita menopause memiliki risiko hipertensi yang lebih tinggi dibanding yang belum menopause. Perubahan hormonal dan biokimia setelah menopause adalah penyebab utama perubahan tekanan darah tersebuthormon pada ovarium dapat memodulasi tekanan darah.Perubahan hormon tersebut membuat perempuan mengalami peningkatan sensitivitas terhadap garam dan penambahan berat badan.Kedua hal tersebut berpotensi memicu tekanan darah yang lebih tinggi. ${ }^{2}$

Salah satu faktor terjadinya hipertensi adalah dari asupan makanan, faktor makanan yang dianggap mempunyai peranan salah satunya adalah asupan protein, lemak jenuh dan lemak tak jenuh. Mekanisme hubungan asupan protein dengan tekanan darah dengan adanya asam - asam amino yang memiliki peran penting dalam regulasi pembuluh darah. ${ }^{3} \mathrm{~L}$ - arginin yang banyak terdapat pada protein hewani dan nabati merupakan substrat dari nitrit oksida (NO), nitrit oksida berfungsi sebagai vasodilator dan pengatur pertahanan vaskuler. Asam amino triptofan dan tirosin yang juga banyak terdapat pada protein hewani mempunyai efek anti hipertensi karena adanya pembentukan serotonin pada system syaraf pusat. ${ }^{3}$

Pada 2 studi observasional utama yaitu INTERMAP dan the Chicago Western Electric Study telah membuktikan sumber protein nabati berpengaruh terhadap penurunan tekanan darah

\section{METODE PENELITIAN}

Penelitian ini merupakan penelitian obervasional analitik dengan desain cross sectional. Penelitian dilakukan pada tanggal 7 24 Mei 2019. Subjek dari penelitian ini adalah wanita dengan kelompok umur 48 - 65 tahun di wilayah kerja Puskesmas Sukamerindu. Teknik pengambilan sampel dalam penelitian ini karena mengandung asam amino esensial yang fungsinya untuk meningkatkan proses transport aktif dari darah kedalam sel otot dan dapat meningkatkan sintesis protein didalam sel otot dan sel hati dengan menghambat katabolisme protein menggunakan insulin maka terjadinya aliran darah perifer meningkat maka terjadilah peningkatan curah jantung yang mempengaruhi penurunan tekanan darah.

Lemak terbagi menjadi asam lemak jenuh atau Saturated Fatty Acid (SFA), asam lemak tidak jenuh tunggal atau Monounsaturated Fatty Acid (MUFA) dan asam lemak tidak jenuh ganda atau Polyunsaturated Fattty Acid (PUFA). Penggolongan tersebut memiliki peranan penting terhadap kesehatan seseorang (WHO 2008).Asupan lemak jenuh/SFA yang berlebih dapat memicu terjadinya aterosklerosis yang merupakan salah satu faktor risiko hipertensi terkait dengan peningkatan resistensi dinding pembuluh darah. ${ }^{5}$

Asupan lemak tak jenuh terbagi menjadi 2 yaitu asam lemak tidak jenuh tunggal atau Monounsaturated Fatty Acid (MUFA) dan asam lemak tidak jenuh ganda atau Polyunsaturated FatttyAcid (PUFA). Asupan MUFA dan PUFA yang tinggi dapat menurunkan kadar kolostrol Low Density Lipoprotein (LDL) sehingga memperkecil risiko peningkatan tekanan darah oleh adanya penumpukan kolestrol. ${ }^{6}$

Pada tahun 2018 didapatkan data wanita berusia 46-65 tahun yang berobat karena hipertensi di Puskesmas Sukamerindu yaitu sebanyak 356 orang, masih tingginya kasus wanita berusia 46-65 tahun yang mengalami hipertensi di wilayah kerja puskesmas Sukamerindu.

menggunakan purposive sampling dan jumlah sampel yang di dapatkan yaitu 67 responden.

Data dikumpulkan menggunakan formulir food frequency questionnaire (FFQ) semi kuantitatif. Tekanan darah diukur menggunakan spignomanometer yang di periksa langsung oleh perawat dan bidan. 


\section{HASIL}

Analisis univariat digunakan untuk menggambarkan distribusi frekuensi dari variabel dependen dijelaskan pada Tabel 1 masing-masing variabel independen maupun

dibawah ini:

Tabel 1. Distribusi Frekuensi Konsumsi Protein, Lemak Jenuh Dan Lemak Tak Jenuh Dengan Kejadian Hipertensi Pada Wanita Menopause Diwilayah Kerja Puskesmas Sukamerindu Kota Bengkulu Tahun 2019.

\begin{tabular}{lcc}
\hline Variabel penelitian & n & $\begin{array}{c}\text { Persentase } \\
(\%)\end{array}$ \\
\hline Konsumsi protein & & \\
1. Tidak baik & 42 & 62,7 \\
2. Baik & 25 & 37,3 \\
Konsumsi SFA & & \\
1. Tidak baik & 54 & 80,6 \\
2. Baik & 13 & 19,4 \\
Konsumsi MUFA & & \\
1. Tidak baik & 63 & 94,0 \\
2. Baik & 4 & 6,0 \\
Konsumsi PUFA & & \\
1. Tidak baik & 34 & 50,7 \\
2. Baik & 33 & 49,3 \\
Kejadian hipertensi & & \\
1. Tidak baik & 35 & 52,2 \\
2. Baik & 32 & 47,8 \\
\hline
\end{tabular}

Berdasarkan Tabel 1 didapatkan hasil bahwa konsumsi Protein pada wanita menopause tidak baik $(\leq 80 \%$ atau $\geq 100 \%)$ dari $\mathrm{AKG}$ sebanyak $62,7 \%$. Konsumsi Lemak jenuh/SFA tidak baik > $10 \%$ dari energy total AKG sebanyak $80,6 \%$ Konsumsi lemak tak jenuh tunggal/MUFA tidak baik $\leq 15 \%$ dari energy total AKG sebanyak 94\%. Konsumsi lemak tak jenuh ganda/PUFA tidak baik $\leq 6 \%$ dari energy total AKG sebanyak 50,7\% Wanita menopause yang mengalami hipertensi sebanyak $52,2 \%$. Analisis bivariat dilakukan untuk mengetahui hubungan antara variabel independen (konsumsi protein, lemak jenuh dan lemak tak jenuh) dengan variabel dependen (kejadian hipertensi) dengan menggunakan uji chi-square.

Tabel 2. Analisis Hubungan Konsumsi protein, lemak jenuh dan lemak tak jenuh dengan kejadian hipertensi pada wanita menopause di Wilayah Kerja Puskesmas Sukamerindu Kota Bengkulu Tahun 2019.

\begin{tabular}{clccccccc}
\hline \multirow{2}{*}{ Zat Gizi } & \multirow{2}{*}{ Konsumsi } & \multicolumn{2}{c}{ Hipertensi } & \multicolumn{2}{c}{ Tidak } & \multicolumn{2}{c}{ Total } & Nilai p \\
\cline { 3 - 9 } & & $\mathbf{n}$ & $\mathbf{\%}$ & $\mathbf{n}$ & $\mathbf{\%}$ & $\mathbf{n}$ & $\mathbf{\%}$ & $\boldsymbol{p}$ \\
\hline Protein & 1. Tidak baik & 33 & 78,6 & 9 & 21,4 & 42 & 100 & 0,000 \\
& 2. Baik & 2 & 8,0 & 23 & 92,0 & 25 & 100 & \\
\multirow{2}{*}{ SFA } & 1. Tidak baik & 32 & 59,3 & 22 & 40,7 & 54 & 100 & 0,042 \\
& 2. Baik & 3 & 23,1 & 10 & 76,9 & 13 & 100 & \\
MUFA & 1. Tidak baik & 33 & 52,4 & 30 & 47,6 & 63 & 100 & 1,000 \\
& 2. Baik & 2 & 50,0 & 2 & 50,0 & 4 & 100 & \\
\multirow{2}{*}{ PUFA } & 1. Tidak baik & 14 & 41,2 & 20 & 58,8 & 34 & 100 & 0,111 \\
& 2. Baik & 21 & 63,6 & 12 & 36,4 & 33 & 100 & \\
\hline
\end{tabular}


Berdasarkan Tabel 2 menunjukan bahwa wanita menopause dengan konsumsi protein tidak baik mengalami hipertensi sebanyak $78,6 \%$. Konsumsi lemak jenuh/SFA tidak baik mengalami hipertensi sebanyak 59,3\%, konsumsi lemak tak jenuh tunggal/MUFA tidak baik mengalami hipertensi 52,4\%. Selanjutnya wanita menopause dengan konsumsi lemak tak

\section{PEMBAHASAN}

Asupan protein pada subjek penelitian bersumber dari protein nabati dan protein hewani. Hasil penelitian didapatkan dari hasil wawancara dengan responden menggunakan metode Semi Quantitatif Food Frequency Questioner (SQ-FFQ) penggunaan sumber bahan makanan protein yang paling sering di konsumsi oleh masyarakat di wilayah kerja puskesmas sukamerindu yaitu daging ayam, hati ayam, kulit ayam, ikan sungai/tawar dan ikat laut, sedangkan pada protein nabati yang sering dikonsumsi adalah tahu dan tempe.

Sejalan dengan penelitian Rika dan Nurmasari (2015) menyatakan bahwa ada hubungan signifikan asupan protein total dan protein hewani dengan tekanan darah sistolik dan diastolic, Asam amino arginin, yang banyak terdapat pada sumber protein hewani seperti daging sapi, daging ayam, telur, sosis, jerohan, danikan yang meliputi ikan air tawar, asin dan tambak,bertindak sebagai substrat dari nitrit oxide (NO). ${ }^{7,3,8}$

Asam amino lain seperti triptofan dan tirosin yang banyak terdapat pada protein hewani mempunyai efek anti hipertensi karena adanya pembentukan serotonin pada sistem syaraf pusat. ${ }^{9}$ Asam amino triptofan mampu mempengaruhi neurotransmitter atau substansi humoral yang dapat mengontrol tekanan darah. ${ }^{10}$ Peningkatan kadar serotonin plasma dan peningkatan pergantian serotonin dapat menurunkan tekanan darah. ${ }^{11}$

Pada 2 studi observasional utama yaitu Intermap dan the Chiago Western Electric Study telah membuktikan adanya hubungan bahwa sumber protein nabati berhubungan dengan penurunan tekanan darah,protein nabati memiliki kandungan asam amino esensial Leusin, Isoleusin, Valin, Triptofan, Fenilalanin, Treonin, Lisin dan Histidin, kecuali Metionin. Asam amino esensial dapat meningkatkan proses transport aktif dari darah kedalam sel otot dan jaringan lainnya dan meningkatkan sintesa jenuh ganda/PUFA tidak baik yang mengalami hipertensi $41,2 \%$. Secara statistic ada hubungan antara konsumsi protein, lemak jenuh/SFA dengan kejadian hipertensi $(\rho=$ value $<0,05$ ) dan tidak ada hubungan antara konsumsi lemak tak jenuh tunggal/MUFA dan lemak tak jenuh ganda/PUFAdengan kejadian hipertensi $(\rho=$ value $>0,05)$.

protein di sel otot dan sel hati dengan mengaktifkan ribosom dan menghambat proses katabolisme protein dengan bantuan insulin. Hal ini berefek terhadap sistem kardiovaskuler yaitu dapat meningkatkan aliran darah perifer serta menurunkan resistensi perifer, sehingga terjadi peningkatan curah jantung yang berpengaruh terhadap penurunan tekanan darah. ${ }^{4}$

Berdasarkan hasil uji statistik terdapat hubungan konsumsi lemak jenuh/SFA dengan kejadian hipertensi dengan nilai $(\mathrm{pValue}<0,05)$ yaitu $(\mathrm{p}=0,042)$. Dalam penelitian ini diketahui bahwa wanita menopause dengan konsumsi lemak jenuh tidak baik memiliki peluang risiko 4.848 kali lebih besar mengalami hipertensi. Berdasarkan hasil wawancara sumber lemak jenuh yang setiap hari dikonsumsi responden yaitu minyak kelapa sawit, 45 responden sering juga mengkonsumsi santan atau kelapa parut dengan frekuensi makan setiap hari atau $3-6 \mathrm{x} /$ minggu.

Penelitian ini sejalan dengan penelitian Fera Yulistiana dkk (2017) bahwa terdapat hubungan asupan lemak jenuh berlebih dengan hipertensi $\mathrm{p}=(0,000)$. Dalam penelitian Lidyawati (2014) terdapat hubungan asupan lemak jenuh berhubungan dengan kejadian hipertensi $(p=0,02) .{ }^{12}$ Dimana wanita menopause yang mempunyai asupan lemak jenuh berlebih berisiko 5,76 kali lebih besar untuk menderita hipertensi dibandingkan wanita menopause yang mempunyai asupan asam lemak jenuh baik. Hasil ini sesuai dengan penelitian yang dilakukan oleh Syukraini yang menyebutkan bahwa risiko untuk menderita hipertensi pada orang yang mengkonsumsi lemak terutama lemak jenuh dalam jumlah tinggi adalah 8,7 kali lebih besar dibanding dengan orang yang mengkonsumsi lemak jenuh dalam jumlah rendah. ${ }^{13}$

Asupan asam lemak jenuh yang berlebih dapat menyebabkan terjadinya dislipidemia yang merupakan faktor risiko aterosklerosis. ${ }^{14}$ 
Aterokslerosis dapat memicu terjadinya hipertensi.Hal ini disebabkan karena pembuluh darah yang mengalami aterosklerosis selain terjadi peningkatan resistensi pada dindingnya juga mengalami penyempitan, sehingga memicu peningkatan denyut jantung dan peningkatan volume aliran darah yang berakibat pada meningkatnya tekanan darah serta terjadi hipertensi. ${ }^{5}$

Sumber bahan makanan MUFA adalah minyak zaitun, kacang almond dan alpokat, berdasarkan hasil wawancara langsung dengan responden selama penelitian diketahui bahwa dari 67 responden hanya 7 orang yang mengkonsumsi minyak zaitun dengan frekuensi konsumsi setiap hari dan $3 \mathrm{x} /$ minggu dan ada 33 responden yang sering mengkonsumsi alpokat dengan frekuensi makan 3-6x/ minggu.

Asupan MUFA yang tinggi memiliki pengaruh dalam penurunan kadar kolestrol LDL sehingga dapat memperkecil risiko peningkatan tekanan darah oleh adanya penumpukan kolestrol. ${ }^{14}$ Tetapi di penelitian ini tidak terdapat hubungan antara konsumsi MUFA dengan kejadian hipertensi pada wanita menopause hampir seluruh responden 94\% dalam kategori hipertensi maupun tidak hipertensi masih kurang dalam mengkonsumsi asupan MUFA. Penelitian

\section{KESIMPULAN}

Konsumsi protein, lemak jenuh (SFA), lemak tak jenuh tunggal (MUFA) dan lemak tak jenuh ganda (PUFA) pada wanita menopause terhadap kejadian hipertensi hampir sebagian termasuk dalam persentase tidak baik. Ada hubungan antara konsumsi protein dan lemak

\section{DAFTAR PUSTAKA}

1. Robinson,Joan. $\mathrm{M}$ dan Lyndon Saputra. 2014. Buku Ajar Visual Nursing Jilid Satu. Tangerang Selatan : Bina rupa Aksara Publisher.

2. Ellie Whitney \& Sharon Rady Roflfes. 2005. Understanding Nutrition (10th Ed). Thomson-Wadsworth

3. Mitsumasa Umesawa, Shinichi Sato, Hironori Imano, Akihiko Kitamura, Takashi Shimamoto, Kazumasa Yamagishi, et al. 2009. Relations between protein intake and blood pressure in Japanesemen and women: the Circulatory Risk in CommunitiesStudy (CIRCS)1-3. Am J Clin Nutr, 90: 377-384 ini sejalan dengan penelitian yang menjelaskan bahwa bahwa tidak ada hubungan asupan MUFA dengan hipertensi. ${ }^{15,16}$

Bahan makanan yang diketahui sumber PUFA meliputi bahan makanan mengandung minyak wijen, minyak ikan, minyak jagung, minyak biji matahari, biji-bijian dan kacangkacangan, dalam penelitian ini hanya 4 orang yang mengkonsumsi minyak wijen dengan frekuensi konsumsi setiap hari dan 3x/minggu, sedangkan 23 responden yang sering mengkonsumsi kacang tanah dalam olahan lotek dengan frekuensi makan 3-6x/ minggu.

Asupan makanan tinggi PUFA akan menurunkan LDL darah, dimana penurunan LDL juga akan memperkecil risiko peningkatan tekanan darah oleh penumpukan kolestrol. ${ }^{17}$ Selain itu PUFA yang terdiri dari omega 3 dan omega 6 dapat mempengaruhi tekanan darah dengan meningkatkan produksi prostaglandin di ginjal dan jaringan lain, dimana prostaglandin berperan sebagai vasodilator. ${ }^{18}$ Pada penelitian mengenai asupan PUFA tidak ada hubungan dengan tekanan darah pada wanita post menopause secara statistic. Hal ini sesuai dengan penelitian yang menyatakan bahwa PUFA yang terdiri atas asam linoleat dan linolenat berkolerasi negatif dengan tekanan darah. ${ }^{8,16}$

jeunh (SFA) terhadap kejadian hipertensi pada wanita menopause, sedangkan pada lemak tak jenuh Mufa maupun Pufa tidak adanya hubungan terhadap kejadian hipertensi pada wanita menopause.

4. Ridwan, M. 2009. Mengenal, Mencegah, Mengatasi Silent Killer Hipertensi. Jakarta: Pustaka Widyamara

5. Anwar TB. 2004. Dislipidemia Sebagai Faktor Resiko Penyakit Jantung Koroner.

Medan: Fakultas Kedokteran Universitas Sumatra Utara

6. Agustini, Zuhro.2013. Hubungan Asupan Lemak (Lemak Jenuh, Tak Jenuh, Kolesterol) dan Natrium terhadap Tekanan Darah pada Pasien Hipertensi di Poli Penyakit Dalam RSP Batu.Skripsi. Universitas Brawijaya Malang 
7. Purwani, Rika dan Widyastuti, Nurmasari. 2015. "Hubungan Asupan Protein dengan tekanan darah pada remaja".Tidak diterbitkan.Program Studi Ilmu Gizi Fakultas Kedokteran Universitas Diponegoro Semarang. Jakarta, 4(2): 534-540

8. Ainun Anindita R. \& Adriyan Pramono.2013."Hubungan asupan monosakarida, PUFA, arginin, asam glutamat dan massa lemak tubuh dengan tekanan darah pada wanita postmenopause". Journal of nutrition college. 2(2): :277-286

9. Justin R. Buendia, M. Loring Bradlee, Martha R.Singer, and Lynn L. Moore. 2014. Diets Higher in Protein Predict Lower High Blood Pressure Risk in Framingham Offspring StudyAdults. American Journal of Hypertension.

10. Kotchen TA, Kotchen JM. Nutrition.2006. Diet, and Hypertension. In: Shils ME. Modern Nutrition in Health and Disease 10th edition. Philadelpia: Lippincott Williams and Wilkin . 1095-1102

11. Ardiansyah, Hitoshi Shirakawa, Yuto Inagawa, Takuya Koseki and Michio Komai. 2011. "Regulation of blood pressure and glucose metabolism induced by Ltryptophan in stroke-prone spontaneously hypertensive rats". Nutrition \&Metabolisme, 8:45

12. Fera Yulistiana., Sri M.D \& Eunike R.R. 2017. "Korelasi asupan makan, stress dan aktivitas fisik dengan hipertensi pada wanita menopause".Unnes Journal Of Publich Health, 6 (1): $36-42$

13. Irza S. 2009. Analisis Faktor Hipertensi Pada Masyarakat Nagara Bungo Tanjung Sumatera Barat [Skripsi]. Fakultas Farmasi Universitas Sumatera Utara Medan.

14. Rahardja, E. M. 2004. Faktor gizi dalam regulasi tekanan darah, Ebers Papyrus, 10(3).

15. Dewi, Novitasari dan Yudhya, Erry.M. 2016. "Asupan lemak (MUFA), Kalsium, Indeks Massa Tubuh, dan Hipertensi pada Wanita Postmenopause di Pulau Sumatera (Analisis Data Sekunder Riskesdas 2007)". Jurnal Nutrire Diaita, 8(2): 85-93

16. Lidiyawati dan Apoina K. 2014."Hubungan Asupan Asam Lemak Jenuh, Asam Lemak Tidak Jenuh Dan Natrium Dengan Kejadian Hipertensi Pada Wanita Menopause Di Kelurahan Bojongsalaman". Journal of Nutrition College. Vol. 3(4): hal.612-619.

17. Adkins Y, Darshan SK.2010.“ Mechanism Underlying the Cardioprotective Effects of Omega-3 Polyunsaturated Fatty Acids".J Nut Bio, 21: 781-792

18. Ueshima H, et al. 2007. Food Omega - 3 Fatty Acid Intake of Individuals (Total, Linolenic Acid, Long Chain) And Their Blood Pressure: INTERMAP Study. Hypertension, 50: hal $313-319$. 